\title{
Sosyalist Iktisadi Hesaplama Tartışması: Metodolojik Bir İnceleme
}

\author{
Serdar Göcen*
}

\section{Öz}

İktisadi hesaplama tartışmasında Mises ve Hayek tarafından sosyalizme yöneltilen eleştiriler, aynı zamanda hâkim iktisat modelinin de eleştirileri olarak ele alınmalıdır. Walrasgil genel denge ve tam rekabet piyasası modelleri sosyalist iktisatçılar Taylor ve Lange tarafından sosyalizmin ekonomik olarak başarılı olacağını göstermek için kullanılmıştır. Hem liberal hem de sosyalist iktisatçılar tarafından, Mises ve Hayek'in bu iki modele getirdikleri eleştiriler tam olarak kavranamadığı için sosyalizmin, en azından piyasa ekonomisi kadar başarılı olacağı şeklinde yanlış bir kanı hâkim olmuştur. Yakın zamanda ortaya çıkan kompleksite iktisadının hâkim iktisada yönelttiği metodolojik eleştiriler, Mises ve özellikle Hayek tarafından yöneltilen eleştirilerin haklılığını göstermiştir. Böylece, Mises ve Hayek'in sosyalizmde iktisadi hesaplamanın imkânsız olduğu şeklindeki eleştirileri kompleksite iktisadı ile bir kez daha ortaya konmuştur. Sonuç olarak, sosyalist iktisatçıların Walrasgil genel denge ve tam rekabet piyasası modellerine dayanmayan yeni modellerle sosyalizmde iktisadi hesaplamanın mümkün olduğunu göstermeleri gerekmektedir.

Anahtar Kelimeler: Sosyalizm, İktisadi Hesaplama Tartışması, Kompleksite İktisadı.

\section{Socialist Economic Calculation Debate: A Methodological Review}

\section{Abstract}

The Mises and Hayek's critique of socialism in the economic calculation debate should also be considered as a critique of the mainstream economic model. Walrasian general equilibrium and perfect competition market models were used by socialist economists, Taylor and Lange, to show that socialism would be economically successful. Mises and Hayek's critique of these two models could not be fully understood by both liberal and socialist economists. Therefore, a misconception prevailed that socialism would be at least as successful as the market economy. The recently developed methodological criticisms of the mainstream economics by the complexity economics have justified the arguments of Mises and particularly of Hayek. Thus, Mises and Hayek's critiques that economic calculations are impossible in socialism have been put forward once again with complexity economics. As a result, socialist economists need to demonstrate that economic calculation in socialism is possible with new models that are not based on Walrasian general equilibrium and perfect competition market models.

Keywords: Socialism, Economic Calculation Debate, Complexity Economics.

*Arş. Gör. Dr. | Osmaniye Korkut Ata Üni., İktisat Bölümü | serdargocen@osmaniye.edu.tr ORCID: 0000-0002-5742-191X | DOI: 10.36484/liberal.749329

Liberal Düşünce Dergisi, Yıl: 25, Sayı: 99, Yaz 2020, ss. 27-48.

Gönderim Tarihi: 8 Haziran 2020 | Kabul Tarihi: 2 Eylül 2020 


\section{Giriş}

İktisat bilimine yapılmış en önemli katkılardan biri Ludwig von Mises ile başlayan ve bir süre sonra Fredrich August Hayek'in devraldığı “Sosyalizmde İktisadi Hesaplama Tartışmaları” ile iktisat literatürüne kazandırılan özel mülkiyetin önemi, bilgi problemi, denge dışıllk, rasyonelliğin anlamı, genel denge analizinin ve tam rekabet piyasasının eleştirileridir. Bu katkılar, her biri çok önemli olmasına rağmen, iki iktisatçının döneminde diğer iktisatçılar tarafından yeterince kavranamamıştır. Dönemin hâkim iktisat metodolojisi ve sosyalizmin entelektüeller arasındaki popülerliği bu kavranamayışın temel nedenleri olarak gözükmektedir. Metodolojik olarak Neo-Klasik iktisadın dişında kalan Avusturya Okulu ve onun önde gelen temsilcileri Mises ve Hayek'in görüşleri, bu alanda çalışan az sayıda iktisatçı dışında bilinmeyen ve önemi anlaşılamayan bir şekilde kalmıştır.

Son yılarda Mises ve Hayek tarafından genel denge ve tam rekabet piyasası modellerine yöneltilen eleştiriler yeni iktisat akımları tarafından dile getirilmeye başlanmıştır. Bunlar arasında kompleksite iktisadı, denge dışı analiz, heterojen ajanlar, ajanlar arası etkileşim, global bir kontrolcünün olmaması gibi özelliklerle sahiptir (Arthur, vd., 1997; Arthur, 2013; Vaughn, 1999). Bu özellikler, gerek Neo-Klasik iktisada yönelik eleştirileri gerekse görüşlerinin, özellikle Menger ve Hayek tarafından temsil edilen Avusturya Okulu çizgisine benzerlikleri bakımından önemlidir.

Bu çalışmada amaç, sosyalizmde iktisadi hesaplama tartışmalarını iktisat bilimindeki metodolojik gelişmeler çerçevesinde ele almak ve Avusturyan iktisatçıları ile sosyalist iktisatçılar arasındaki bu tartışmada haklı olan taraf konusunda kararı iktisat bilimdeki metodolojik gelişmeler çerçevesinde vermektir. Walrasgil genel denge ve tam rekabet piyasası modelleri çerçevesinde iktisadi hesaplama tartışmaları ele alındıktan sonra, kompleksite iktisadının bu tartışmaları nasıl etkileyeceği tartışılmaktadır.

Walrasgil genel denge ve tam rekabet piyasası modellerinin varsayımları bir taraftan Avusturya Okulu'nun metodolojik olarak Neo-Klasik iktisattan kopuşuna neden olurken diğer taraftan Fred M. Taylor ve Oskar Lange tarafından temsil edilen sosyalist iktisatçıların sosyalizmin ekonomik olarak başarılı olacağı yönündeki görüşlerinin haklı görülmesini sağlamıştır. Kompleksite iktisadının, söz konusu iki modelin hatalı varsayımlara dayanıyor olması şeklindeki eleştirileri, özellikle Hayek'in sosyalizme yönelttiği eleştirileri hatırlatmaktadır. Kompleksite iktisadının metodolojik çerçevesinden bakıldığında, Walrasgil genel denge ve tam rekabet piyasası modellerinin 
hatalı olduğu görülmektedir. Bu nedenle, bu iki modele dayanan Taylor ve Lange modellerinin de hatalı olduğu sonucuna ulaşılmaktadır.

Bu çalışmanın ilk bölümünde, sosyalizm iktisadi hesaplama tartışmaları ele alınmaktadır. Burada Mises ve Hayek sosyalizmin ekonomik olarak başarısız olacağını savunan, Taylor ve Lange sosyalizmin başarılı olacağını savunan iktisatçılar olarak incelenmektedir. İkinci bölümde, Walrasgil genel denge ve tam rekabet piyasası modellerinin hâkim olmasının bu iki grup iktisatçının görüşleri üzerindeki ve sosyalizmin ekonomik olarak başarılı olacağ1 yönündeki düşüncelere etkisi tartışılmaktadır. Üçüncü bölümde, öncelikle kompleksite kavramı ve kompleksite iktisadı ele alınmakta, daha sonra Avusturya Okulu ile kompleksite iktisadı arasındaki benzerlikler tartışılmaktadır. Bu bölümün son alt başlığında ise, kompleksite iktisadının Taylor ve Lange'nin görüşlerini geçersiz kıldığı görüşü incelenmektedir. Dördüncü bölüm, genel değerlendirmelerden oluşan sonuç bölümüdür.

\section{Sosyalizmde İktisadi Hesaplama Tartışması: Kısa Bir Tarihçe}

Ludwig von Mises'in 1920 yılındaki çalışması ile başlayan sosyalizmde iktisadi hesaplama tartışmalarının kökeni 19. yüzyılda Karl Marx ve diğer sosyalist iktisatçıların kapitalizme yönelttikleri eleştirilere ve sosyalizmin piyasa ekonomisinden daha etkin bir ekonomik sistem olduğu görüşüne dayanmaktadır. Marx sosyalizm hakkında pek bir şey yazmamış olmasına rağmen, onun kapitalizm analizinden hareketle sosyalist bir ekonominin işleyici üzerine çalışan iktisatçllar olmuştur. Ancak günümüzde hâlâ sosyalist bir ekonominin nasıl işleyeceğini anlamak için başvurulacak kaynakların ne olduğu konusu muğlâktır. Esasında sosyalistlerin bu konu üzerine düşünmeleri de Mises'in çalışması ile başlamıştır. ${ }^{1}$

Bir piyasa ekonomisinde hesaplamayı mümkün kılan şey nedir? Klasik iktisatçıların ve Marx’ın bu soruya vereceği cevap değer teorisi ile ilişkilidir. Klasik iktisatçıların ve Marx'ın dayandığı emek-değer teorisine göre, her bir malın fiyatı, o malı üretmekte kullanılan emek miktarınca belirlenmektedir. Bu maliyet temelli yaklaşıma göre, fiyatın oluşumunda kullanım değeri hiçbir etkiye sahip değildir. Fiyat tamamen malın üretim maliyeti ile belirlenmektedir. Kullanım değeri ile mübadele değeri arasındaki ayrım Marx’da

1 Oskar Lange “On the Economic Theory of Socialism: Part One” isimli çalışmasında Mises'in sosyalizme yönelttiği eleştirileri ele alırken, müstehzi bir biçimde de olsa, böyle bir soruna işaret ettiği için Mises'e teşekkür etmektedir. Ancak, geleceğin sosyalist ekonomisinde, Mises'in Kamulaştırma Bakanlığı'nda veya Merkezi Planlama Kurulu'nda yer alması gerektiğini söylemesi, Mises'in eleştirilerini çözülebilecek sorunlar olarak gördüğünü ve tam olarak anlamadığını göstermektedir. 
bulunuyor olsa da kullanım değerine de dayanan bir değer teorisinin geliştirilmesi marjinalist devrim ile birlikte olmuştur.

Marx (2018)'a göre, değerin oluşumunda etkili olan mübadele değeridir. Dolayısıyla iki şeyin mübadele edilmesi, mübadele değerleri eşit olan iki şeyin el değiştirmesi anlamına gelmektedir. Bu işlem sonucunda, iki tarafın refahında bir değişiklik olmaz. Mübadele edilen iki şey aynı değere sahiptir ve el değiştirmeleri neticesinde onlara sahip olanların durumunda bir iyileşme ortaya çıkmaz. Eğer bir tarafın durumu iyileşmişse, bu ancak diğer tarafın durumunun kötüleşmesi, yani kandırılması neticesinde olmuştur. Görüldüğü gibi Marx kullanım değeri kavramının farkında olsa da, onun değer teorisinde kullanım değerinin hiçbir rolü yoktur.

Genel olarak marjinalist devrimin, özelde Carl Menger'in “İktisadın Prensipleri” kitabı ile değer teorisine kattığı yenilik kullanım değerinin de fiyatların oluşumunda (değer teorisinde) kullanılmasıdır. Bir malın kullanımı kişilere göre farklılık gösterir. Öyleyse kullanım değeri subjektif bir unsurdur. İki şeyin mübadelesinde, tarafların her ikisinde de kendileri için kullanım değeri daha yüksek olan şeyi almaları, böylece durumlarını iyileştirmeleri mümkündür. Değer teorisine bu subjektif unsurun katılması klasik iktisatçıların ve Marx'ın kullandığı objektif değer teorisine göre bir ilerlemeyi temsil etmekte ve mübadele sıfır toplamlı bir oyun olmaktan çıkıp, kazan-kazan durumuna dönüşmektedir. Sonraki bölümde görüleceği gibi, Lange’nin sosyalizmde hesaplama sorununu çözmek için tüketim piyasasında özel mülkiyete izin vermesi, fiyatın maliyet temelli olarak belirlenmesinin mümkün olmadığının ve kullanım değerinin fiyatı belirlemekte bir rolü olduğunun kabulü anlamina gelmektedir. ${ }^{2}$

Ancak, bu subjektif değerin (kullanım değerinin) iktisadi hesaplamada kullanılması mümkün değildir. Mises (1990)'e göre, hesaplama yapabilmek için objektif bir unsura gerek duyulmaktadır. Mises'in sosyalizme yönelik eleştirisi, sosyalizmin bu objektif unsurdan yoksun olmasına yöneliktir. Mises (1990) bu objektif faktörün parasal fiyatları olduğunu belirtmektedir. Fiyat, kıtlık (arz şartları) ve kulanım değeri (talep şartları) ile belirlenmektedir. Parasal fiyatların ortaya çıkması ve rasyonel bir iktisadi hesaplamaya imkân vermesi için hem tüketim mallarının hem de üretim mallarının özel mülkiyete ait olması gerekir.

Özel mülkiyet piyasa ekonomisi kararlara kılavuzluk eden fiyatları üretir, ve kâr ve zarar muhasebesi kaynakların ve zamanın alternatif fırsatlar

2 Oskar Lange, Marxist emek-değer teorisini modern ekonomik denge teorisinin daha ilkel bir versiyonu olduğu ve hiçbir analitik değer taşımadığı yönünde eleştirmektedir (Selik, 1982: 113-114). 
arasındaki dağılımı ve yeniden dağılımı için gerekli geri bildirimi sağlar. Parasal hesaplama bize ekonomik değişim denizi üstünde kılavuzluk etmede asla mükemmel değildir, fakat o bizi kimi zaman dalgalı olan sularda yol bulmaya muktedir kılar (Boettke, 2013: 5-6).

Sosyalist bir ekonomide de para kullanımı olacaktır. Ancak, sosyalist ekonominin özelliği üretim araçlarında özel mülkiyete müsaade etmemesidir. Böyle bir durumda para sadece tüketim mallarının mübadelesinde kullanılabilir. Mises (1990) parasal hesaplamanın mümkün olması için üretim mallarının da mübadele edilebilmesini sağlayacak şekilde özel mülkiyetin sağlanması gerektiğini belirtmektedir. Sosyalist ekonomide paranın varlığı ile rekabetçi ekonomide paranın varlığı arasındaki farklılık üretim araçlarındaki mülkiyetin şeklinden kaynaklanmaktadır. Sosyalist ekonomide üretim araçları mübadeleye dâhil edilemediği için parasal bir değere sahip olamamaktadır. Bu nedenle sosyalist ekonomide paranın varlığı, rekabetçi ekonomideki gibi bir işlev görmemektedir. (Mises, 1990: 4).

Mises'in sosyalizme yönelik eleştirilerine verilen cevaplar iki farklı iktisatçının görüşleri ile incelenebilir. Burada ele alınacak olan Fred M. Taylor'ın görüşleri sistematik olarak ifade edilmemiş genel kanaatler görüntüsündedir. Yine de tartışmanın akışını doğru şekilde aktarabilmek amacıyla Taylor'ın görüşlerine yer verilecektir. Ayrıca, daha sonra ele alınacak Oskar Lange'nin görüşlerini de etkilediği için Taylor'ın görüşlerini incelemek önem taşımaktadır.

Taylor (1929) ilk olarak piyasa ekonomisinin nasıl çalıştığını açıklayarak sosyalist bir ekonominin de bu işlevleri yerine getirmek için nasıl kurgulanacağını anlatmaktadır. Piyasa sisteminde gelir sahibi olan vatandaşlar piyasaya gittiklerinde talep ettikleri malları üreticilerden satın alırlar. Taylor burada üç önemli aşama öngörür. Birincisi, gelir sahibi vatandaşlar. Sosyalizmde vatandaşlara gelir devlet tarafından temin edilir. İkincisi, vatandaşların gelirleri ile piyasada mal talep etmeleri ve üçüncüsü piyasada bu talebi karşılayacak malların üretilmesi. Taylor’a göre, ikinci ve üçüncü aşamada devlet piyasanın yerini alır. Vatandaşlar devlet tarafından sağlanan gelirleri ile devletin ürettiği ürünleri alırlar ve diğer taraftan da piyasa ekonomisinde olacağı gibi devlete üretmesi gereken mallar için rehberlik ederler (Taylor, 1929: 1).

Vatandaşların gelirinin devlet tarafından belirleniyor olması, genel olarak vatandaşların çıkarlarının belirli bireylerin çıkarlarına feda edilememesini sağlamaktadır. Vatandaşların sağlanan bu gelir aracılığıyla devletin ne üreteceğini belirlemesi ise, her bireyin zevk ve tercih özelliklerinin devlet tarafından belirlenen bir tüketim standardına feda edilememesini sağlamaktadır (Taylor, 1929: 4-5). 
Taylor’a göre, sosyalizmin ekonomik planı dört koşula dayanmaktadır. Birincisi, devlet tarafından vatandaşlara sağlanacak gelirin belirli şartlara bağlı olmasıdır. Taylor bu koşulların ne olduğunu açıklamamaktadır ancak bu koşulların varlığı zorunludur. İkincisi, devlet gelir dağıtımında bir bütün olarak vatandaşların çıkarına yönelik hareket edecektir. Böylece devletin sağladığı gelirler vasıtasıyla vatandaşların harcama kararları sosyalist kararlar olarak ortaya çıkacak ve malların sosyal önemlerini sergileyen fiyatlar ortaya çıkacaktır. Üçüncüsü, malların fiyatlarının olmasıdır. Böylece, vatandaşlar belli bir malı talep edip etmeyeceklerine karar verebilirler. Dördüncüsü, devlet malların üretim maliyetlerini bilmeli ve tüm malların fiyatlarını üretim maliyetlerine eşitlemelidir (Taylor, 1929: 2-3).

Taylor sosyalist bir plan için gerekli olan bu dört koşuldan ilk üçünün sağlanacağından emindir. Dördüncü koşulun sağlanması atıf sorunun çözümüne bağlıdır.

Atıf problemi, her üretim faktörünün üretim sürecindeki efektif öneminin belirlenmesidir. Bu bilgi olmaksızın, yetkililer açıkça herhangi bir metanın kaynak maliyetini hesaplayamazlar; bu nedenle bu mal için doğru satış fiyatını belirleyemezler; ve sonuç olarak bu makaleye göre tek doğru yöntem olan hangi metaları üretmeleri gerektiğini belirleme yöntemini kullanamazlardı (Taylor, 1929: 6).

Taylor atıf sorunun çözümü için deneme-yanılma metodunu önermektedir. Deneme-yanılma metodu beş aşamada anlatılır. (1) Faktör değerleme tabloları oluşturulur ve bu tablolar oluşturulurken her bir faktöre, onun gerçek değerine en yakın olduğu düşünülen değer verilir. (2) Üretim sürecini yönetirken bu verilen değerler tamamen doğru değerler olarak kullanılır. (3) Elde edilen sonuçlar, bu değerlerin bir kısmının yanlış olduğunu ortaya çıkarabilir. (4) Yanlış sonuçlar ortaya çıktığında faktör tabloları güncellenir. (5) Hiçbir yanlış değerleme kalmayana kadar bu süreç tekrar edilir (Taylor, 1929: 7). Böylece, faktörlerin miktarlarında meydana gelecek fazlalıklar ve eksiklikler, sonraki dönemde bu faktörlerin daha az ve daha fazla kullanımı ile dengelenecektir.

Oskar Lange, Mises'e yönelik cevap veren bir diğer sosyalist iktisatçıdır. Lange'ye göre, iktisadi hesaplamanın anlamı alternatifler arasında seçim yapmaktır. Bu seçimin yapılması için genelleştirilmiş fiyatlara ihtiyaç vardır. Mises'in hatası bu geniş anlamdaki fiyatlar ile iki mal arasındaki değişim oranı anlamındaki dar anlamda fiyatı karıştırmasıdır (Lange,1936: 54).

Lange iktisadi hesaplama problemin şu üç bilgi ile çözüleceğini belirtir: (1) Tercih eylemine yön veren tercih ölçeği, (2) alternatiflerin sunulduğu şartların bilgisi, (3) ulaşılabilir olan kaynakların miktarına ilişkin bilgi ( Lange, 1936: 54). 
Lange (1936) birinci ve üçüncü bilginin sosyalizmde bulunduğu kanaatindedir. İkinci bilginin de sosyalizmde ulaşılabilir olduğu gösterilirse, sosyalizmde iktisadi hesaplamanın mümkün olduğu gösterilmiş olur. Lange (1936)'ye göre, birinci ve üçüncü bilgilerin veri olması durumunda, ikinci bilgi bir malı diğerine dönüştüren teknik imkânlar ile belirlenebilecektir.

Piyasanın dengeye ulaşmayı deneme-yanılma yöntemi ile sağladığını belirten Lange, bunun Walras'ın ardışık denemeleri ile yapıldığını belirtmektedir (Lange, 1936: 59). Lange deneme-yanılma yöntemi ile dengeye ulaşma probleminin sosyalizmde nasıl çözüleceğini açıklamaktadır. Sosyalist ekonomide tüketici mal ve hizmetleri için bir piyasa bulunur. Ancak, üretim ve sermaye malları için piyasa bulunmaz. Üretim ve sermaye mallarının fiyatları alternatifleri yansıtan genelleştirilmiş fiyatlardır. Bu sosyalist ekonomide denge iki koşulla sağlanır. Birinci koşul, veri alternatif indeksler altında tüketiciler ve emek sahibi olarak bireyler ve sermaye ve doğal kaynakların (yani üretimin) yöneticisi olarak kamu memurları belirli ilkelere göre kararlarını verirler. İkinci koşul, fiyatlar talep edilen miktar ile arz edilen miktarı eşitlemek için koşulları yaratır. Bu iki koşulun sağlanması iktisadi sisteminin organizasyonunu ifade eden üçüncü bir koşulu meydana getirir. Bu iktisadi organizasyonda emek dışındaki üretim faktörleri kamu mülkiyeti altındadır. Bu nedenle tüketici gelirleri bu üretim faktörlerinin sahipliğine göre değişmeyecektir. Üçüncü koşula göre, iktisadi sistemin organizasyonu geliri düzenleme esaslarına göre belirlenir (Lange, 1936: 61).

F. A. Hayek iktisadi hesaplama tartışmasına farklı bir perspektif getirmiştir. Hayek'in temel vurgusu bilginin doğası üzerinedir. İktisadi hesaplamanın yapılabilmesi, iktisadi hesaplama sorunun nasıl çözüleceği yaşadığımız dünyanın şartları ile ilişkilidir.

Eğer tüm bilgiye sahipsek, eğer veri tercihler üzerinden başlayabilirsek ve eğer var olan araçlarla ilgili tüm bilgiye hâkimsek, sorun tamamen mantıksal boyutludur. Var olan araçların en iyi kullanımı sorusunun yanıtı, varsayımlarınızda gizidir. Bu optimizasyon probleminin çözümünü sağlayan şartlar, en iyi matematiksel olarak ifade edilebilir. Kısaca, iki mal ya da faktör arasındaki marjinal ikame oranları, tüm farklı kullanımlarda birbirinin aynı olmalıdır (Hayek, 2007: 153).

Hayek'e göre bilginin karakteri iktisadi hayatta çözülmesi gereken problemi bundan çok daha farklı hale getirmektedir:

O daha çok toplumun bireylerinden biri tarafından bilinen, kaynakların, nispî önemi, yine yalnızca bu bireylerce bilinen amaçlar için en iyi kullanımının nasıl sağlanacağı problemidir. Veya daha kısa ifade edersek, toplam olarak hiç kimseye verilmeyen bilginin kullanımı problemidir" (Hayek, 2007: 154). 
Hayek (2007)'e göre bilginin temel niteliği dağınık, parçalı, çelişik ve kümülatif hale getirilemeyecek özelliklere sahip olmasıdır. Toplumda her birey farklı, küçük bilgi parçacıklarına sahiptir ve bu bilgi parçacıkları tek bir elde toplanamaz. Bu nedenle merkezi bir planlamanın ihtiyaç duyduğu bilgilere ulaşması mümkün değildir. Hayek (2007) bireysel planlama ile kolektif (merkezi) planlama arasında bir ayrım yapmaktadır. Her birey kendi iktisadi faaliyetlerini kendi planları doğrultusunda gerçekleştirir ve bunu yaparken kendi bilgi parçacıklarını ve ulaşabildiği diğerlerinin sahip olduğu bilgi parçacıkları kullanır. Ancak merkezi planlama, bu dağınık bilgi parçacıklarının kümülatif olarak sahip olunmasına bağlıdır. Bu ise bilginin karakteri ile örtüşmemektedir.

Bu sistemlerden hangisinin daha etkin olacağı, var olan bilginin hangi sistemde tam olarak kullanılacağına ilişkin bekleyişlerimize bağlıdır. Bu, kısaca, kullanmamız gereken, ama başlangıçta çok sayıda farklı bireyler arasında dağılmış bulunan tüm bilginin, tek bir merkezi otoritenin kontrolüne verilmesi durumunda mı, yoksa diğerleri ile planlarını uyuşturmak için ihtiyaç duyulduğunda (kullanılmak üzere) ilave bilginin bireylerce taşınması durumunda mı, daha başarılı olacağımıza bağlıdır (Hayek, 2007:155).

Hayek (2007) teknik (teorik) bilginin planlama için yeterli olmadığı görüşündedir. Planlama zamanın ve mekânın değişen şartlarına ilişkin bilgiyi gerektirir. Bu tür bilgi veri olarak var olmadığından ancak iktisadi faaliyetle (girişimsel faaliyetle) elde edilir. Zamanın ve mekânın şartları değişkendir. Bu bilginin de değişken bir niteliğe sahip olduğunu göstermektedir. Bu nedenle bilgi sürekli olarak yeniden keşfedilmelidir.

İnsan eylemindeki bu girişimsel element, toplumdaki dağınık bilgiden meydana gelen hatalar nedeniyle meydana getirilen pür kâr sinyallerine cevaptır. Problemin kaynağı Hayek'in dağınık bilgisidir: Merkez planlama, dağınık bilgi problemi ile baş etmek için araca sahip değildir ve onun aşırı merkezileşmiş olması, piyasanın keşif sürecini, eğer tamamen sekteye uğratmazsa, engelleyecektir (Kirzner,1984: 416).

Hayek burada bilimsel bilginin iktisadi hesaplama konusundaki sınırlarına dikkat çekmektedir. Bilimsel bilgi seviyesindeki artış iktisadi problemi çözmek için yeterli değildir. İktisadi hesaplama için gerekli olan, dağınık, parçalı ve çelişkili özelliğe sahip mekân ve zamana ait özel şartların bilgisi, bilimsel bilginin edinilmesi ve arttırılması ile elde edilemez. Bu nedenle, en iyi iktisatçı ve bürokratlardan kurulu bir komitenin hesaplama sorununu çözmesi mümkün değildir.

Yapmamız gereken, teorik eğitimimizi (training) tamamladıktan sonra bir işte ne kadar öğrenmemiz gerektiğini, çalışma yaşamamızın ne kadar büyük kısmını özel işleri öğrenmek için harcadığımızı, yerel ve belirli şartlara ilişkin kişi bilgisinin yaşamamızda ne kadar önemli olduğunu anımsamaktan ibarettir. Yeterince kullanılmayan bir makinenin ya da vasıflarından çok 
daha iyi yararlanabilecek bir kişinin varlığını bilmenin ve bunu kullanımı ya da arzın kesintiye uğradığı bir dönemde yaratılabilecek bir mal stoğunun farkında olmanın, en az daha iyi alternatif tekniklerin bilgisi kadar sosyal yararı vardır. Yaşamı boş, avare-vapurlar gibi harcamaktansa çalışarak kazanan bir nakliyeci olsun, tüm bilgisi büyük ölçüde geçici fırsatlardan ibaret olan bir emlak komisyoncusu olsun ya da mal fiyatlarının bölgesel farklılıklarından kazanç sağlayan bir arbitraj yapan kişi olsun, başkalarının bilmediği anlık şartların özel bilgisine dayalı olarak çok faydalı bir işlev görürler (Hayek, 2007: 155-156).

Merkezi planlama ile ilgili bir diğer problem, iktisadi hayatın sürekli olarak değişim içinde olmasıdır. Başlangıçta yapılan planlar, yukarıda sayılan nedenler nedeniyle zaten doğru olmayacaktır. Ancak doğru olsalar bile, sürekli değişen şartlar nedeniyle, plan sürekli yenilenmelidir. Her bir yenilenme ihtiyacı, bilgiye ilişkin yukarda bahsedilen sorunları tekrar devreye sokacaktır.

İktisadi hesaplama sorununun çözümü için fiyat sistemi önemli bir role sahiptir. Fiyat sistemi, dağınık bilginin keşfedilmesi, taşınması ve kullanılmasını sağlamaktadır. Böylece, fiyat sistemi aracılığı ile dağınık bilginin elde edilmesi ve kullanımında iş bölümünün yaratılması sağlanmaktadır. Burada deneyimin önemi ortaya çıkmaktadır.

Piyasa sistemi bireyler arasında, bir bakıma, bilginin iş bölümünü sağlamaktadır. Her ekonomik aktör piyasada eylemde bulunurken sadece dağınık bilginin sahip olduğu kısmına göre hareket etmeyecektir. Diğerlerinin eylemleri ve bu eylemlerinin sonuçları da onun için data teşkil etmektedir. Ayrıca, kendi yaptığı hatalar ve doğrular sayesinde edindiği yeni bilgilere ek olarak, diğer aktörlerin hata ve doğruları vasıtalarıyla da yeni bilgilere ulaşacaktır (Göcen, 2015: 392).

\section{Tartışmayı Kim Kazandı - I: Genel Denge ve Tam Rekabet Piyasası Modellerine Göre Bir Analiz}

Bu bölümde iktisat biliminde hâkim metodoloji haline gelen Walrasgil genel denge ve tam rekabet piyasalarının kullanımının iktisat hesaplama tartışması üzerindeki etkileri incelenmektedir. İlk olarak tam rekabet piyasası kavramının ortaya çıkışı ve Mises-Hayek tarafından tam rekabet piyasası ve genel dengeye yöneltilen eleştiriler ele alınmakta, daha sonra Taylor ve Lange'nin sosyalist ekonomide iktisadi hesaplamaya yönelik çözümlerinin genel denge ve tam rekabet piyasası modellerine dayandığı tartışılmaktadır.

\section{Tam Rekabet Piyasası ve Mises-Hayek'in Tam Rekabet Piyasasına Yönelik Eleştirileri}

Sosyalist ekonomide iktisadi hesaplama tartışmalarında Mises-Hayek ile temsilen liberal kanadın mı, Taylor-Lange ile temsil edilen sosyalist kanadın 
mı kazandığına karar vermek için iktisat bilimindeki metodolojik gelişmelerin (analiz metodunun) incelenmesi önemlidir. 1930'lu yıllara gelindiğinde ana-akım iktisadın yöntemi Walrasgil genel denge ve tam rekabet piyasası varsayımlarına bağlıdır (Kirzner 2016). Tam rekabet piyasa (TRP) modeli hem sosyalist iktisatçılar hem de Avusturya Okulu'na mensup olanlar dışında, liberal iktisatçılar tarafından bir ideal piyasa ekonomisi olarak kabul edilmiştir. Kirzner (2016) burada liberal iktisatçılardan Frank Knight'ın rolünü öne çıkarmakta ve 1930'ların başlarına kadar Neo-Klasik iktisadın içerisinde yer alan Avusturya İktisat Okulu'nun heteredoks bir okul haline gelmesini bu metodolojik kopuşla açıllamaktadır. Stigler, Frank Knight’ın tam rekabet piyasası modeline katkısını şu şekilde anlatmaktadır.

Tam rekabet piyasası kavramı tam formülasyonunu Frank Knight'ın Risk, Belirsizlik ve Kâr (1921) kitabında aldı. Bu çalışmadaki titiz tartışma, iktisatçılar için genel olarak titizlikle tanımlanmış bu kavramın sade doğasının anlaşılmasını sağladı ve 1930'larda bu kavrama karşı yaygın reaksiyonun yolunu hazırladı (Stigler, 1957:11).

Tam rekabet piyasası özellikle iki unsuru ile Avusturya Okulu'nun piyasa ekonomisi kavramından ayrılmaktadır. Bunlar rasyonellik ve tam bilgidir. İlk unsur olan rasyonellik, Knigth'ın tanımına göre, toplumun üyelerinin eylemlerini ve onların sonuçlarını biliyor olmaları ve eylemlerini bu sonuçların ışığında gerçekleştirmeleridir (Knigth, 1921: 76-77). Bu rasyonellik tanımının iktisat biliminde uygulanışı şu şekilde özetlenebilir:

Rasyonel insan varsayımı, ana-akım iktisadın kullanımında, insanı sadece iktisadi çıkarları olan ve onların gerçekleşmesi için çabalayan bir insan olarak tanımlar. Rasyonel insan dendiğinde, bilginin tamamına sahip olan, herhangi bir bilgi kısıtıyla karşılaşmayan bir insan anlamı vardır. Bununla iliş̧kili olarak rasyonellik varsayımının diğer özelliği insanların hata yapmayacağı varsayımıdır. Buna göre, hata yapmak gibi insani bir unsur, ana-akım iktisadın rasyonel insan varsayımına aykırı olması nedeniyle analiz dışı bırakılır (Göcen, 2015: 394).

Mises (2008) rasyonelliği farklı bir şekilde açıklamaktadır. Rasyonel olma, tüm bilgiye sahip ve hata yapmayan bireyler anlamına gelmemektedir. Bireyler, amaçlarını gerçekleştirmek için eylemde bulunurlar. Rasyonellik, amacı gerçekleştirmeye yönelik eylemin kendisidir ve böylece, amacın kendisinin doğruluğundan ve eylemin sonucundan ayrılarak, eylemin kendisine bağlanmaktadır. Mises (2008)'e göre rasyonellik eylemde bulunmaktır ve bu nedenle tanım gereğidir. Başlangıçtaki amacın yanlış ve sonucun başarılı olmaması rasyonelliği geçersiz kılmamaktadır.

İkinci unsur olan tam bilgi varsayımı, rasyonellik varsayımının tamamlayıcısıdır. 
Eğer insanlar kusursuz bir öngörüye sahiplerse, durağan bir ekonomi tam dengeci dengeyi başarmak için gerekli değildir ve bu dengeyi başarmak için yeterli de değildir, çünkü beklenmeyen kuraklık ve sel gibi nedenler yüzünden hâlâ tarihsel olmayan dalgalanmalar olabilir. Tam ve hatasız ayarlamaların yapılabilmesi, tüm ilgili şartların değişmediği durumda (yani ekonomi durağan iken), bu şartlara ilişkin gerçekçi olarak sahip olunan tüm bilgiyi gerektirir (Stigler, 1957: 11-12).

Knight (1921) bu tam bilgi durumunun doğal olduğunu belirtmektedir. Durgun koşullar altında herkes kendi davranışlarını etkileyen durum ve etrafında olanlar hakkında bilgiye sahip olacaktır (Knight, 1921: 79).

TRP kavramının 1930'lardan itibaren iktisatçılar için bir model olmuştur (Stigler, 1957: 17). TRP, tam bilgi ve rasyonellik varsayımları altında Walrasgil genel dengenin nasıl sağlanacağını göstermektedir. Günümüzde dahi TRP piyasa ekonomisinin mükemmel temsili olarak görülmekte ve onun varsayımlarından uzaklaşmalar piyasa başarısızlığı olarak ele alınarak ekonomiye devletin müdahalesini meşrulaştırma aracı olarak kullanılmaktadır. Piyasa ekonomisine yönelik eleştirilerin bir diğer yönü ise, özellikle iktisat teorisinde gelişmelerle birlikte, tam rekabet piyasasının hipotetik yapının gerçeği yansıtmadığı yönündedir. Bu eleştiriler en az iki açıdan yanlıştır. Birincisi, TRP sadece piyasa ekonomisinin savunusunda ya da piyasa ekonomisi analizlerinde kullanılan bir model değildir. Dönemin hâkim iktisadi modeli olarak TRP, hem sosyalist hem de liberal iktisatçılar tarafından kullanılır hale gelmiştir. Bunun istisnası Avusturya Okulu'dur. Gerek Mises ve gerekse Hayek çalışmalarında tam rekabet piyasasına eleştiriler yöneltmektedirler. İkincisi, Mises ve Hayek'in TRP'yi hiçbir zaman ideal bir serbest piyasa modeli olarak kullanılmamaları, aksine onu eleştiriye tabi tutmalarıdır.

TRP piyasası rasyonellik ve tam bilgi varsayımlarına dayanan bir genel denge analizidir. Ekonomide genel dengenin nasıl sağlanacağı ve farklı denge durumları arasındaki geçişler incelenmektedir. Avusturya Okulu temsilcilerine göre, ekonomi dengeye ulaşmaz. Mises (2008) TRP ifadesini kullanmaz. Dengeye ulaşmış ekonomiyi dengeli dönüşüm ekonomisi (evenly rotating economy-ERE) olarak adlandırmaktadır. Mises (2008)'e göre, ERE iktisatçllar için analizlerini geliştirdikleri ideal bir durum değil, analize başlangıç noktasıdır. Denge durumunda, fiyat değişmelerinin olmaması ve durağan şartlar nedeniyle girişimsel faaliyete yer yoktur (Mises, 2008: 247). Değişimin ve eylemin olmadığı "böyle bir katı sistem, yaşayan, seçim yapan ve hataya maruz kalan insanlarla doldurulmamıştır; ruhsuz, düşünmeyen otomatonların dünyasıdır; insan toplumu değildir, karınca tepesidir" (Mises, 2008: 248). Mises (2008) ERE’nin ekonominin asla ulaşmayacağı bir denge durumunu temsil ettiğini ve gerçek hayattaki, dengeden uzaklaşmalar ve dengeye yaklaşmalar 
şeklindeki ekonomik işleyişe uymadığını belirtmektedir. Mises gibi Hayek de denge analizini eleştirmektedir:

Denge konsepti tek bir bireyin eylemlerine uygulandığında açık bir anlama sahiptir. Bu bağlamda denge, toplumun tüm üyelerinin eylemleri, periyod boyunca planların sırasıyla icrası ile var olur (Hayek, 1948: 35).

Denge analizinin tüm önermeleri eylemler arası ilişkiler hakkındaki önermelerdir. Bir işinin eylemlerinin dengede olduğunu, belli bir dereceye kadar, onlar bir planın parçası olarak anlaşılabildiğinde söylenebilir (Hayek, 1948: 36).

Hayek'in bilgi konusundaki analizleri ise, TRP'nin tam bilgi varsayımının aksini işaret etmektedir. Ayrıca rekabet tanımı da TRP'den farklıdır. TRP içersinde rekabet, homojen mallar üreten çok sayıda firma ve piyasaya giriş serbestisinden oluşmaktadır. Fiyatlar piyasada veri olarak belirlenmekte ve üreticiler fiyat üzerinde bir etki yaratamamaktadırlar. Tüm üreticiler, belirlenmiş fiyat seviyesinden tüm ürünlerini satmaktadırlar.

Rekabet bir keşif süreci olarak girişimsel faaliyet yoluyla bilginin keşfedilmesi ve kullanımıdır (Kirzner, 1984). Böyle bir piyasa ekonomisinde denge oluşmaz, ayrıca bu arzu edilir de değildir. Gerçek dünya riskler ve belirsizliklerle sarılıdır. Bilgi problemi, dengenin oluşmaması, risk ve belirsizlik gibi unsurlar, ideal bir piyasa sisteminin TRP'nin durgun dünyası değil, tam tersine hatalara imkân tanıyan, girişimsel ve keşifsel faaliyetlerle bilgi probleminin üstesinden gelmek üzere organize olmuş bir piyasa ekonomisi olduğunu göstermektedir (Herbener, 1992). Bu nedenle, TRP bir ideali değil tersine piyasa ekonomisinin zıddını temsil etmektedir.

Deneyimleri ile bilgiye keşfedecek olan geniş anlamda girişimcidir. Yani, NeoKlasik refah iktisadi analizinin tam bilgi varsayımdan uzaklaşıldığında, karşı karşıya kalınan bilgisizlik, bu bilginin keşfini gerektirir burada da girişimci ve onun deneyimlerinin piyasa ekonomisinde oynadığı rol ortaya çıkar. Bilgideki değişiklik planını değiştirir ve dengeyi tahrip eder (Hayek, 1948: 36).

Mises ve Hayek perspektifine göre, TRP arzu edilen bir piyasa değildir. Oradaki rekabet ve piyasa terimleri yanıltıcıdır. TRP, piyasa ekonomisinin ideal bir dünyada çalışma şeklinin bir gösterimini sağlamaz. Alternatif iktisadi sistemlerin analizi, idealize modeller ile değil, dünyanın gerçekte nasıl bir yer olduğu ile uyumlu olarak ele alınmalıdır. Bu nedenle, TRP’nin gerçekçi olmayan yapısını ideal olarak kabul edip sonra piyasa ekonomisini bu ideale uymadığı için eleştirmek ve ekonomiye müdahale için gerekçe yaratmak mümkün değildir. Bu nedenle TRP'den uzaklaşmalar piyasa ekonomisini terk etmek için gerekçeler sunmaz.

Mises ve Hayek'in TRP'ye yönelttikleri eleştiriler onun gerçekçi olmayan yapısı ve piyasa ekonomisini temsil etmemesi ile ilgilidir. TRP modeli, 
iktisadi problemin yanlış anlaşılmasına neden olmaktadır. Bu perspektiften hareketle görülüyor ki TRP, Mises ve Hayek tarafından kullanılan bir model değildir. Serbest piyasa ekonomisi TRP tarafından değil, bu iki iktisatçının çalışmaları ile ele alınmalıdır.

\section{Tam Rekabet Piyasası ve Sosyalist İktisatçılar}

Taylor ve Lange'nin iktisadi hesaplama tartışmasına dair yazıklarında TRP vurgusu açıktır. Hesaplama sorunun çözümü Walrasgil genel denge ve TRP analizine dayanan varsayımlar ve kurgular ile çözülmeye çalışılmıştır. Lange ve Taylor, tüketim mallarında özel mülkiyete izin vererek kullanım değeri problemini çözmüş olsalar da sermaye mallarında kamu mülkiyeti kurarak Mises'in üretim araçlarının kamu mülkiyeti altında olması nedeniyle sosyalist ekonomilerin başarısız olacağı yönündeki eleştirisini, TRP varsayımı ile çözmeye çalışmışlardır. Ancak TRP varsayımı kaldırıldığında, üretim araçlarının kamu mülkiyeti, tüketicilerin talepleri toplanmış olsa dahi, alternatif üretim araçlarının hangilerinin kullanılacağı ve kullanılamayacağı hususunda yardımcı olmayacaktır.

Taylor ve Lange sosyalizm altında hesaplama sorununu çözerken TRP modelini kullanmaktadırlar. Bu modelin hâkim iktisat modeli olması nedeniyle de TRP şartları altında sosyalist hesaplamanın mümkün olduğu, dolayısıyla bu tartışmanın Taylor ve Lange lehine sonuçlandığı kabul edilmiştir. “Hayek'in siyasi sonuçlarıyla hemfikir olan ekonomistler bile bilgi sorununun sosyalist planlama için ciddi sorunlar yaratacağına inanmadılar" (Vaughn, 1999: 246).

TRP ideal bir piyasa modeli değildir. Tersine, piyasa ekonomisi ile merkezi planlama arasında bir fark olmayacağı ya da merkezi planlamanın daha başarılı olacağı sonucuna ulaşılmasına imkân veren bir modeldir. Taylor ve Lange TRP'yi ideal bir ekonomik model olarak almakta ve sosyalist ekonomiyi bu modele göre kurmaktadırlar. Lange'nin serbest piyasalara yönelik eleştirisi, TRP şartlarından uzaklaşmasına yöneliktir.

Bununla birlikte, sosyalist ve özel girişimin rekabetçi rejiminde kaynakların dağıtılması ilkeleri arasındaki biçimsel analoji, ekonomik denge teorisinin hem özel girişimin rekabetçi rejimi hem de sosyalist rejim için geçerli olan, bilimsel tekniğini sağlar. Gerçek kapitalist sistem, Bayan Robinson ve Profesör Chamberlin'in analizi ile Walras ve Marshall'ınkinden çok daha iyi açıklanmaktadır. Ancak Walras ve Marshall'ın çalışmaları sosyalist bir sistemin problemlerini çözmede daha yararlı olacaktır. Sonuç olarak, Bayan Robinson ve Profesör Chamberlin, gelecek nesillere moda ve çılgınlık olarak görülecek şeyi anlamak için gerekli teorik araçları tarih öğrencilerine temin etmek için iktisat tarihi bölümüne transfer olmayı kabul etmedikçe, sosyalizm altında işlerini kaybetme tehlikesi ile karşı karşıya kalırlar" (Lange, 1937: 127). 
Lange'in bu yaklaşımına göre, sosyalizmi piyasa sisteminden üstün k1lan faktör, sosyalizmde TRP şartlarının daha iyi sağlanmasıdır. Robinson ve Chamberlin'in sosyalizmde işlerini kaybetme tehlikesi ile karşı karşıya kalmalarının nedeni, sosyalizmde TRP şartlarının her zaman geçerli olacağı ve eksik rekabet şartlarının oluşmayacak olmasıdır. Bu nedenle, genelde Avusturya Okulu'nun, özel olarak Mises ve Hayek'in TRP'na yönelik eleştirileri sosyalizme yönelik eleştiriler olarak okunmalıdır.

\section{Tartışmayı Kim Kazandı - II: Kompleksite İktisadı ve Hesaplama Tartışmaları}

Bu bölümde ilk olarak kompleksite iktisadı ve kompleksite iktisadı ile Avusturya Okulu arasındaki benzerlikler incelenmektedir. Daha sonra kompleksite iktisadının metodolojik özelliklerinin iktisadi hesaplama tartışmaları üzerindeki etkisi ele alınmaktadır.

\section{Komleksite İktisadı}

Kompleksite iktisadı, diğer pek çok bilimdeki kompleksite kavramının iktisada uygulanması ile iktisadı Neo-Klasik iktisada alternatif bir yaklaşım sunmaktadır. Kompleksite kavramının mutabakata varılmış bir tanımı bulunmamaktadır (Durlauf, 2012: 46). Seth Llyod 45'ten fazla kompleksite tanımı tespit etmiştir (Rosser, 2015: 595).

Arthur kompleks sistemleri, bireylerin değişen eylemlerinin sonuçlarını ve bireyler arası etkileşim ile eylemleri ve bu eylemler neticesinde yaratılan sonuçlara verilen cevapları dikkate alan sistemler olarak tanımlamaktadır (Arthur, 2013: 11). Vaughn'a göre ise, kompleksite lineer olmayan, birçok bağımsız değişkene sahip sistemlerdir (Vaughn, 1999: 242).

Kompleks sosyal sistemlerin temel özellikleri şunlardır: (i) potansiyel olarak heterojen ve uyarlanabilir birçok farklı bölümden oluşurlar; (ii) doğrudan karşılıklı bağımlılıklarını temsil eden kısımlar arasında önemsiz olmayan bir ilişki kümesi içerirler; ve (iii) katmanlı bir ontolojiye sahiptirler, daha alt ontolojik düzeylerdeki elementlere geri besleme sağlayabilen ortaya çıkış özellikleri vardır (Gräbner, 2017: 393-394).

Kompleksite teorisinin bir diğer önemli özelliği “ortaya çıkış” (emergent) yaklaşımıdır. Ortaya çıkış, meydana gelen sonucun ajanlar arasındaki etkileşim ile meydana geldiğini, bu sonucun ajanların bireysel özeliklerinden farklılaştığını ve bu sonuca ilişkin açıklamalar ile bireysel ajanlara ilişkin açıklamaların uyumlu olmadığını vurgulamaktadır (Vaughn, 1999: 243). 
Ortaya çıkışın ajanların etkileşiminin sonucu olmasının önemi, bir tür kendiliğinden gelişime vurgu yapıyor olmasıdır. Bu kendiliğindenlik (i) merkezi denetleyicinin olmaması ve (ii) tam bilginin olmaması şeklinde iki unsurun ortaya çıkışına neden olur (Vaughn, 1999: 243).

Amacımız bakımından en önemlisi, kompleks sistemler adaptif sistemler olma eğilimindedir. Yani, bir anlamda bu sistemde ajanlar çevreleriyle başa çıkmayı daha iyi öğrenirler. Onlar sürekli olarak, eylemlerinin sonucu olarak alacakları ödüllere göre, diğer bir deyişle, yeni organizasyonlarının üretkenlik başarısına göre, temel yapılarını organize ve yeniden organize ederler. Ajanlar ödüllerinin diğer ajanların eylemlerine de oldukça bağlı olduğunu fark ettiklerinde, bazı ajanlarla işbirliği yapma ve çevresel uyum sağlama becerilerini geliştirmek için diğerleri ile rekabet etmeye yönelirler (Vaughn, 1999: 244).

"Kompleksite ekonomistleri yapıların ortaya çıkışını ve ekonomide kalıpların gelişmesini inceler” (Arthur 1999). Ekonominin bir kompleks sistem olarak ele alınması, iktisadi analizin metodunu da değiştirmektedir.

O, eylemlerin ve stratejilerin sürekli değiştiği, yapıların sürekli biçimlendiği, standart denge analizinde olmayan olguların ortaya çıktığı ve mikro ve makro arasındaki ayrımın önemli hale geldiği, farklı bir görüş sunar (Arthur 2013:1).

Arthur (2013)'a göre, kompleksitenin iktisada uygulanması, Neo-Klasik iktisattan tamamen farklı bir analiz metodu sunmaktadır. Bu bakımdan, kompleksite iktisadını Neo-Klasik iktisadın özel bir durumu olarak düşünmek yanlıştır (Arthur, 2013: 19). Arthur (2013)'un bu yaklaşımı denge analizini, Mises'te ERE analizinin bir başlangıç noktası olması gibi, iktisadi analizin özel bir durumu haline getirmektedir. Neo-klasik iktisadın deterministik, öngörülebilir ve mekanik yapısından farklı olarak, kompleksite kavramının iktisada uygulanması iktisat bilimini süreç odaklı/bağımlı, organik ve sürekli evrilen/gelişen bir biçime sokar (Arthur, 1999: 107).

Arhur’a göre, iktisatta iki önemli problem vardır: genel denge, uluslar arası ticaret ve oyun teorisinde sunulan mal ve hizmet miktarlarının ve fiyatlarının oluşumuna dayanan dağıtım ve yenilik, ekonomik kalkınma, yapısal değişim, düşüncüleri ile sunulan, tarihin, kurumların ve yönetimin rolüne önem veren, ekonominin nasıl ortaya çıktığı, nasıl büyüyeceği ve değişeceğini inceleyen formasyon. Kompleksite iktisadı ikincisi ile ilgilenmektedir (Arhur, 2013: 17).

Böylece metodolojik olarak Neo-Klasik iktisattan ayrılmış bir başka iktisat yapma biçimi ortaya çıkmaktadır. Bu metodolojik ayrımlardan birincisi denge kavramı ile ilgilidir. Walrasgil analiz ve TRP'nin sahip olduğu temel özelliklerden biri ekonomik sorunu bir dengeye ulaşma ve dengede kalma 
sorunu olarak ele almasıdır. Kompleks sistemler sürekli evrimle/gelişme ve yayılma özellikleri ile dengeye ulaşmayı engeller (Arthur, 1999: 107). İkinci metodolojik ayrım, ekonomiyi basit ajanlara ayıran ve bu ajanlar arasındaki etkileşim ve öğrenme gibi etkileşimleri yok sayan Neo-Klasik iktisada karşılık, kompleksite iktisadının ajanlar arası etkileşimin neticesi olarak kendiliğindenliğe ve ajanların adaptif olmalarına önem vermesidir.

Ekonomiyi kompleks bir sistem olarak ele almak, bireylerin birlikte ortaya çıkışına katkı sağladıkları kurumsal yapıya nasıl uyum sağladıklarına ve bu yapının bireysel etkileşimin bir sonucu olarak nasıl sürekli değiştiğine odaklanmak anlamına gelir (Gloria, 2019: 3).

Üçüncü metodolojik ayrım rasyonalite ve bilgi ile ilişkilidir. Neo-Klasik iktisadın rasyonel, tüm bilgiye sahip üreticiler, tüketiciler, devlet adamları ve merkezi planlamacılar çerçevesi, kompleksite iktisadında davranışsal iktisadın sınırlı rasyonellik yaklaşımının kullanılması ile değişmiştir.

\section{Avusturya Okulu ve Kompleksite İktisadı}

Avusturya Okulu ile kompleksite iktisadı arasındaki ilişki genel olarak Menger ve Hayek'in metodolojik görüşleri ile ilişkilendirilmektedir. Avusturya Okulu'na mensup makro iktisatçılar, ekonomiyi kompleks ve adaptif bir sistem olarak görmektedirler ve bunun neticesinde makro iktisadi değişkenler ekonomik ajanların amaçlı eylemleri arasındaki etkileşim ile ortaya çıkan değişkenler olarak ele alınmaktadır (Veetil ve White, 2017:).

Adam Ferguson, Bernard Mandeville, Carl Menger gibi düşünürlerin vurguladığı "kendiliğinden doğan düzen" kavramı kompleksite iktisadının ajanlar arası etkileşim ve ortaya çıkış kavramları ile benzerlik taşımaktadır. Hayek ile birlikte kendiliğinden doğan düzen iktisattan, politik bilim ve hukuka kadar pek çok alana uygulanmıştır. Hayek (2012) doğal olanla, tasarım eseri olan arasında yapılan ayrımın yanıltıcı olduğunu belirtmektedir. Bugün sahip olduğumuz kurumlar ne doğada bulunurlar ne de insan aklının tasarlayabileceği basitliktedirler. Onlar üçüncü bir unsurun, "insan eylemlerinin amaçlanmamış sonuçları”nın, yani kendiliğinden doğan düzenin sonucudurlar. Kendiliğinden doğan düzen, bireylerin amaçlarını gerçekleştirmek üzere eylemde bulunurken birbirleri ile etkileşimleri neticesinde, başlangıçta amaçlanmamış sonuçların ortaya çıkışı anlamına gelmektedir. En bilinen örnekleri, dil, para ve piyasa sistemidir. Bugünkü halleri ile diller doğal olmayan ve fakat tasarlanamayacak kadar da karmaşık yapıdadırlar. İnsanların bin yıllar boyunca birbirleriyle iletişim kurmak için yaptıkları eylemler neticesinde evrilerek günümüzdeki hallerini almışlardır. Para ise, insanların 
mübadele etme yönündeki eğilimlerinin bir sonucu olarak, mübadeleyi kolaylaştırması ve mübadele hacmini arttırması neticesinde ortaya çıkmıştır. Dil ve para, kompleksite iktisatın terminolojisi ile belirtilirse, ajanlar arası etkileşim neticesinde ortaya çıkışın en belirgin örneklerindendir.

Carl Menger "The Origins of Money" adlı eserinde paranın ortaya çıkışını kendiliğinden düzen ile açıklamaktadır. Menger (2009a) paranın organik bir kurum olduğunu belirtmektedir. Bu, paranın bir otorite tarafından bilinçli olarak yaratılmadığı anlamına gelmektedir. Paranın kökenini açıklamak, takas işlemlerinde karşılaşılan sorunların çözümü için ortak mübadele aracı olarak ortaya çıkan malın anlaşılması ile mümkün olmaktadır (Witt ve Beck, 2015:578).

Menger'in kompleksite iktisadı ile ilişkisi bir diğer açıdan Marjinalist Devrim üzerinden de ele alınabilir. Menger (2009b)'in, Leon Walras ve William Stanley Jevons ile aynı dönemde geliştirdiği marjinalist analiz, bu iki iktisatçıdan metodoloji olarak ayrılmaktadır. Kompleksite iktisadı ile ilişkisi bakımından en önemli iki özelliğinden birincisi, Menger'de mübadele ve eylem denge dişında gerçekleşmektedir. İkincisi, Menger'de ekonomi denge dişında ve sürekli bir dinamik süreç içerisinde bulunan bir yapıdır (Rosser, 2015: 603).

Arthur, vd. (1997) kompleksite iktisadına ait altı özellik saymaktadır: Dağınık etkileşim, global bir kontrolcünün yokluğu, kesişen hiyerarşik organizasyon, sürekli adaptasyon, sürekli yenilik ve denge dişı dinamikler (Arthur, vd., 1997: 4-5). Rosser (2015) bu altı özelliği sayarak Avusturya iktisadının ilk beş özelliği taşıdığını, bu nedenle Avusturya iktisadının kompleksite iktisadı ile uyum içerisinde olduğunu belirtmektedir. Denge dışılığın ise, global bir optimuma ulaşamama, sınırlı rasyonellik ve beklenmedik olaylar ve süreçleri vurgulaması nedeniyle Avusturya iktisadı ile uyumlu olmadığını belirtmektedir. Dengesizlik özellikle Hayek'le birlikte vurgulanmaya başlanmış olsa da, kendiliğinden düzenlerin bir optimuma ulaşma anlamında değil, ancak arzu edilen sonuçlar üretmesi bakımında denge dışı olma özelliğine uyum göstermediği görüşündedir (Rosser, 2015: 596). Ancak Rosser, Hayek'in kullandığ1 denge kavramının Walrasgil anlam taşımadığının ve Menger'in ekonomiyi denge dışı dinamik olaylar olarak gören yaklaşımına uyum sağladığının farkındadır (Rosser, 2015: 603). Bu nedenle, Hayek'teki denge kavramı, hâkim iktisadın kullandığı denge kavramından farklı anlam taşımaktadır.

\section{Komleksite İktisadı ve Sosyalist Hesaplama}

Kompleksite iktisadının getirdiği politika sonucu, piyasaların kendi haline bırakılması durumunda krizlere neden olacağı ve piyasa başarısızlığı 
yaratacağı şeklinde yorumlanmaktadır (Arthur, 2013).

Karmaşıklık çok sayıda yerel cazibe durumunu uyarır, olaylar finansal ağlar aracılığıyla yayılır ve bir dizi ekonolojik çözüm ve zorluk üretir ve bu da fazlalığı düzenleme, tercih edilen sonuçlara doğru dürüst olma ve inovasyon koşullarını akıllıca teşvik etme politikaları için bir rol açar (Arthur, 2013: 18).

$\mathrm{Bu}$ açıdan bakıldığında, kompleksite iktisadının piyasa ekonomisinin tam tersi politika çıkarımları yaptığı sonucuna ulaşılmaktadır.

“İktisadın pratik dünyadaki başarısızlıkları büyük ölçüde ekonomiyi dengede görmekten kaynaklanmaktadır” (Arthur, 2013: 18). Arthur (2013) son 25 yılda yaşanan krizlerin hiç birinin kontrolden çıkmış piyasa tarafından çıkarılmadığını ve piyasadaki birkaç oyuncunun manipülasyonunun bu krizlere neden olmadığını belirtmektedir. Bu krizler arasında 2008 krizi, 2010'da yaşanan Euro krizi, Rusya'nın sosyalizmden kopuşu sonrası yaşadığı problemleri saymaktadır. Tüm bu krizlerde iktisat biliminin hatası denge varsayımına dayalı analizler yapıyor olmasıdır. Denge analizi, tanımı gereği, bu krizleri öngöremez ve açıklayamaz. Çünkü dengede iktisadi ajanların davranışlarını değiştirmeleri ve başka bir duruma geçmek için eylemde bulunmaları için hiçbir neden yoktur. Piyasada oluşan, sapmalara neden olan davranışları da bu nedenle öngöremez. Denge analizi, piyasada meydana gelen arızaları tespit etmek için uygun değildir (Arthur, 2013: 18).

Kompleksite iktisadının piyasa başarısızlıklarını ima ettiği ve bu nedenle ekonomi politikaları için yer açtığı düşüncesi ve yukarıda Arthur (2013)'dan alıntılanan, sanki piyasa sistemi lehine gibi görülen, ancak esasında denge analizini piyasanın başarısızlıklarını öngöremediği için eleştiren görüşlerin dayandığı temel bir hata bulunmaktadır. Kompleksite iktisadının ilgi çekici yönü, Neo-Klasik iktisadın yarattığı hayal ürünü bir sistem yerine, iktisadi hayatın olduğu gibi kavramasıdır. Bu Avusturya Okulu'nun da belirgin özelliklerinden biridir. Ancak, kompleksite iktisatçıları piyasa sistemini eleştirirken Neo-Klasik iktisatla bağlarını yeniden kurmaktadırlar. Eleştirdikleri piyasa konsepti, gerçekte ekonominin ve piyasaların nasıl işlediğine dayanmaktan ziyade, Neo-Klasik iktisadın onu hapsettiği Walras, TRP ve denge analizi çerçevesine dayanmaktadır. "Mükemmel, tamamen eksiksiz piyasalar, tıpkı sosyalist hesaplama sorununa uygulanamadıkları gibi, gerçek dünyaya da uygulanamayan analitik bir kurgudur. Piyasa başarısızlıkları, uygulanamaz bir modelin sonucuna ulaşma başarısızlıklardır" (Vaughn, 1999: 253).

Yukarda ele alınan hesaplama tartışmalarında sosyalist iktisatçıların temel iddiası, sosyalizmin kapitalizmden daha büyük maddi refah yaratacağ iddiasıdır. Önceki bölümde gösterildiği gibi bu ancak Walragil genel denge 
ve TRP analizinde gerçekleşebilir. Gerçek dünya, Walras'in genel dengesindeki ve TRP dünyasındaki gibi tam bilgi, rasyonalite ve denge analizine uygun olsaydı, sosyalizm de kapitalizm kadar başarılı olabilirdi. Bu bakımdan, Mises ve Hayek'in sosyalizme yönelik, bilgi eksikliği, rasyonalite, denge dışılık eleştirilerini aynı zamanda Walrasgil genel denge analizinin ve TRP'nin de eleştirileri olarak görmek uygundur. Avusturya Okulu'nun ve Mises ve Hayek'in piyasa sisteminin savunucuları olduğunu bildiğimize göre, piyasa sistemine yapılacak eleştiriler, Neo-Klasik iktisadın hayali dünyasından sapmalara yönelmemeli, bu iktisatçıların çizdikleri piyasa ekonomisi modeline yönelik olmalıdır. Piyasa sistemini bir hayal dünyasını gerçekleştirmediği, o hayal dünyasından saptığı için eleştirmek bir kavrayış sorununa işaret etmektedir. Şu görülmektedir ki, genel kanının aksine, Walrasgil genel denge ve TRP analizleri piyasa sistemini savunmak için ortaya atılmış modeller değildir. Aksine, bu modeller geçerli olsaydı, piyasa sistemi ve sosyalizm arasında iktisadi etkinlik açısından bir fark olmazdı. Taylor ve Lange'nin sosyalizmde iktisadi hesaplamanın mümkün olduğunu göstermek için Walrasgil genel denge ve TRP modellerini kullanmaları tesadüf değildir. Mises ve Hayek tarafından bu modellere yapılan eleştirilerin, kompleksite iktisadı tarafından da dile getirilmesi, sosyalist iktisatçılar için yeni bir meydan okuma ortaya çıkarmaktadır:

Walrasgil genel denge ve TRP modelleri geçerli olmadığına göre Taylor ve Lange'nin iktisadi hesaplama sorununa getirdikleri çözümün geçersiz olduğu bir kez de kompleksite iktisadı ile gösterilmiştir. Sosyalist iktisatçılar, bu iki modele dayanmayan, denge dişılık, bilgisizlik, global bir kontrolcünün olmaması gibi özelliklere dayanan yeni bir modelle sosyalizmde iktisadi hesaplamanın mümkün olduğunu göstermelidirler. Özetle denilebilir ki, Avusturya Okulu mensuplarının eleştirilerine rağmen, uzun süre iktisadın temel analiz modeli olan Walrasgil denge ve TRP modelleri, Taylor ve Lange'nin haklı olduğu yönünde yanlış bir kabule neden olmuştur. Kompleksite iktisadının bu modellere eleştirisi, Mises ve Hayek'in sosyalizm konusunda hakl1lıklarının teslimi anlamına gelmektedir.

Kusurlu bir dünyada, kusursuz bir ekonomik sistem aramak beyhude bir çabadır. Tüketiciler, üreticiler, diğer ekonomik aktörler hata yaparlar. Bu hatalar krize neden olabilir. Piyasa sistemi savunucuları hiçbir hatanın olmadığı bir sistem hayal etmezler. Ancak, devletin ve ekonomik politika yapıcılarının hatalarının çok daha tahrip edici ve yaygın krizlere neden olacağı ve krizden çıkış için uygulanan devlet politikalarının yeni bir krize neden olacağı görüşündedirler. Kompleksite iktisatçılarının, sınırlı rasyonellik varsayımını kabul etmelerine rağmen bunu sadece ekonomik aktörler için uygulamaları, savundukları teorinin imalarını tam olarak kavrayamadıklarını 
göstermektedir. Bilgi problemi piyasa ekonomisin bir özelliği değildir. Kısmen ya da tamamen planlı bir ekonomide de bilgi problemi yaşanır, çünkü bu dünyanın doğal halidir. Bilgi problemi, üretici ve tüketiciler kadar, ekonomik planı yapacak olanlar için de geçerlidir. Bu kişilerin devlet memuru ya da çok iyi iktisatçıları olması durumu değiştirmeyecektir. Aksine, bilgi probleminin planlamacılar için daha büyük sorun olduğu ve çözülemeyeceği önceki bölümlerde Hayek'e atıfla açıklanmıştır. Bu nedenle, kompleksite iktisatçılarının bilgi ve rasyonellik problemlerinden hareketle ekonomiye müdahale sonucunu çıkarmalarının hatalı olduğu görülmektedir.

Kendiliğinden doğan düzenin uygulanması gereken alanlardan biri devlet müdahalelerinin sonuçlarıdır. Kompleksite iktisatçıları, bireylerin rasyonelliğinin sınırlılığı, ortaya çıkış, ajanlar arası etkileşim gibi kavramların devlet müdahalesi için meydana getirdiği sonuçları doğru olarak ele almamaktadırlar. İlk olarak, davranışsal iktisadın kavramsal seti ile sınırlı rasyonellik ve Hayekçi bilgi problemi tüm insanlar için geçerlidir. İnsanların ne merkezi planlama komitesinin bir üyesi olmaları ne de dünyanın en iyi iktisatçıları olmaları onları rasyonel ve tam bilgi sahibi kılacaktır. İkincisi, devlet politikalarının sonuçları, ajanların/bireylerin bu politikalara verecekleri tepkiler ve kendi aralarındaki etkileşim nedeniyle, başlangıçtaki hedeflenenlerden çok farklı olacak şekilde saptacaktır.

\section{Sonuç}

Sosyalizmde iktisadi hesaplamanın imkânına dair 1920'lerde başlayan ve 1930'lara uzanan tartışmanın, iktisatçıların Walrasgil genel denge ve TRP modellerini iktisat biliminin temel analiz metotları olarak belirlemesi nedeniyle, Mises ve Hayek'in yenilgisi ile tamamlandığı görüşü kabul görmüştür. $\mathrm{Bu}$ iki modelin hem liberal hem de sosyalist iktisatçılar tarafından kullanımı, Kirzner (2016)'in belirttiği gibi Avusturya Okulu'nun Neo-Klasik iktisadın dışında kalmasına ve heteredoks bir okul haline gelmesine neden olmuştur. $\mathrm{Bu}$ gelişmenin bir sonucu olarak, Mises'in özel mülkiyetin önemi ve Hayek'in bilginin karakteristiği üzerine yaptıkları vurgular dönemin liberal ve sosyalist iktisatçıları tarafından kavranamamıştır. Metodolojik olarak Walrasgil genel denge ve TRP modellerinin kullanımı Taylor ve Lange'nin sosyalizmin etkin bir iktisadi sistem olduğu sonucuna ulaşmalarına neden olmuştur.

Son yıllarda kompleksite iktisadı, sunduğu alternatiflerle hâkim iktisat metodolojilerini eleştirmektedir. Ekonominin denge dışı durumda ele alınması, denge analizine dayanan hâkim iktisada yönelik en önemli eleştirilendendir. Bu eleştiri, Mises'in ERE'yi bir analize başlamak için basitleşti- 
rici olarak ele almasını ve Hayek'in denge analizi üzerine yaptığı eleştirileri desteklemektedir.

İktisadi ajanların heterojenliği ve aralarındaki etkileşim neticesinde ortaya çıkan sonuçlar Menger-Hayek çizgisinde ele alınan kendiliğinden doğan düzen kavramını hatırlatmaktadır. Ekonomiyi planlamanın ya da ekonomiye yapılan müdahalelerin sonuçları, başlangıçta niyetlenilenlerden çok farklı olmaktadır. Kompleksite iktisadı ile Mises ve Hayek'in görüşlerindeki bu paralellikler, sosyalist hesaplama tartışmasının tekrar değerlendirilmesi için kullanıldığında, Taylor ve Lange'nin argümanları, Walrasgil genel denge ve TRP modellerine dayandıkları için geçerliliklerini kaybetmektedirler.

Sosyalist iktisatçılar, artık iktisatçılar arasında genel kabul görmüş TRP eleştirileri ile yüzleşmelidirler. Onlar, TRP’nin geçerli olmadığı bir dünyada iktisadi hesaplamanın nasıl yapılacağı sorusu ile karşı karşıyadırlar.

TRP iktisatçılar için piyasa sisteminin ideal işleyiş halini gösteren bir model olarak ele alınmış ve TRP'den uzaklaşmalar piyasa sisteminin kusurları olarak görülmüştür. Bu nedenle TRP’ye yönelik yapılan eleştiriler günümüzde dahi piyasa ekonomisi eleştirileri olarak görülmektedir. Bu durum kompleksite üzerine çalışan iktisatçıların bir bölümü için de geçerlidir. Ancak, hayali bir ideal ekonomi modelinin gerçek olmamasına yönelik bu eleştiriler, hem Mises ve Hayek tarafından benzer eleştiriler 1920'lerde ve 1930'larda zaten yapılmış olduğu için hem de bu hayali model piyasa ekonomisinin ideal modelini temsil etmediği için geçersizdir.

\section{Kaynakça}

Arthur, W. Brian, Durlauf, Steven ve Lane, David, A. (1997), "Introduction: process and emergence in the economy", W. Brian Arthur, Steven N. Durlauf ve David A. Lane (ed.), The economy as an evolving complex system II, Series in the Sciences of Complexity, Addison-Wesley, Reading, MA (1997), pp. 1-14

Arthur, W. Brian (1999), “Complexity and the Economy”, Science, s. 284, ss. 107-109.

Arthur, W. Brian (2013), "Complexity economics: a different framework for economic thought", Santa Fe Institute Working Paper, 2013-04-012, ss. 1-22.

Boeetke, Peter (2013), “Mises'in Sosyalizm’inin Önemi”, (çev. Ünsal Çetin), Liberal Düşünce, y. 22 , s. 72 , ss. 65-75.

Durlauf, Steven N. (2012), "Complexity, economics, and public policy”, Politics, Philosophy \& Economics, s. 11(1), ss. 45-75.

Gloria, Sandye (2019), "From Methodological Individualism to Complexity: The Case of Ludwig Lachmann", Review of Political Economy, c. 31, s. 2, ss. 216-232.

Göcen, Serdar (2015), “F. A. Hayek'in Bilgisizlik Teorisi Çerçevesinde Piyasa, Denge ve Planlama", Süleyman Demirel Üniversitesi İktisadi ve Idari Bilimler Fakültesi Dergisi, c. 20, s. 3, ss. 385-404. 
Gräbner, Claudius (2017), "The Complementary Relationship Between Institutional and Complexity Economics: The Example of Deep Mechanismic Explanations", Journal of Economic Issues, c. 51, s. 2, ss. 392-400.

Hayek, Fredrich August (1948), “Economics and Knowledge", Fredrich August Hayek (ed.), Individualism and Economic Order, Chicago: The University of Chicago Press, ss. 33-56.

Hayek, Fredrich August (2007), "Bilginin Toplumda Kullanımı”, (çev. Turan Yay), Liberal Düşünce, c. 12, s. 45, ss. 153-166.

Hayek, Fredrich A. (2012), Hukuk, Yasama ve Özgürlük, (çev.) Atilla Yayla, Mustafa Erdoğan ve Mehmet Öz, İstanbul: Türkiye İş Bankası Kültür Yayınları.

Herbener, Jeffrey M. (1992). "The Role of Entrepreneurship in Desocialization”, The Review of Austrian Economics, c. 6, s. 1, ss. 79-93.

Kirzner, Israel M. (1984), "Economic Planning and The Knowledge Problem”, Cato Journal, c. 4, s. 2, ss. 407-425.

Kirzner, Israel M. (2016), The History and Importance of the Austrian Theory of the Market Process, 48:28 dak. Amerika Birleşik Devletleri: Mercatus Center YouTube Kanalı 2016.

Knight, Frank H. (1921), Risk, Uncertainty and Profit, New York: Hart, Schaffner \& Marx.

Lange, Oskar (1936), "On the Economic Theory of Socialism: Part One", The Review of Economic Studies, c. 4, s. 1, ss. 53-71.

Lange, Oskar (1937), "On the Economic Theory of Socialism: Part Two”, The Review of Economic Studies, c. 4, s. 2, ss. 123-142.

Marx, Karl (2018), Grundrisse: Ekonomi Politiğin Eleştirisi iç̧in Ön Çalışma, (çev. Sevan Nişanyan), İstanbul: Birikim Yayınları.

Menger, Carl (2009a), On the Origins of Money, (çev. C.A. Foley), Auburn, Alabama: Mises Institute.

Menger, Carl (2009b), iktisadın Prensipleri, (çev. A. Kemal Çelebi), Ankara: Liberte Yayınları.

Mises, Ludwig von (1990), Economic Calculation in the Socialist Commonwealth, (çev. S. Adler), Auburn, Alabama: Mises Institute.

Mises, Ludwig von (2008), İnsan Eylemi, (çev. İsmail Aktar), Ankara: Liberte Yayınları.

Rosser, J. Barkley (2015), “Complexity and Austrian economics”, Peter J. Boettke ve Christopher J. Coyne (ed.), The Oxford handbook of Austrian economics, Oxford: Oxford University Press, ss. 594-611).

Selik, Mehmet (1982), Marksist Değer Teorisi, Ankara: S.B.F. Basın Yayın Yüksekokulu Basımevi.

Stigler, George J. (1957), "Perfect Competition, Historically Contemplated", The Journal of Political Economy, c. LXV, s. I, s. 1-17.

Taylor, Fred M. (1929), "The Guidance of Production in a Socialist State", The American Economic Review, c. 19, s. 1, ss. 1-8.

Vaughn, Karen I. (1999), "Hayek's Theory of The Market Order As An Instance of The Theory of Complex, Adaptive Systems", Journal des Economistes et des Etudes Humaines, c. 9, s. 2/3, ss. 241-256.

Veetil, Vipin, P. ve White, Lawrence, H. (2012), "Towards a New Austrian Macroeconomics", Rev Austrian Econ, s. 30, ss. 19-38.

Witt, Ulrich ve Beck, Naomi (2015), “Austrian Economics and Evolutionary Paradigm”, Peter J. Boettke ve Christopher J. Coyne (ed.), The Oxford handbook of Austrian economics, Oxford: Oxford University Press, ss. 576-593. 